\title{
KINERJA MANAJEMEN RANTAI PASOK DENGAN MENGGUNAKAN PENDEKATAN METODE SUPPLY CHAIN OPERATION REFERENCE (SCOR)
}

\author{
PPERFORMANCE OF SUPPLY CHAIN MANAGEMENT USING AN APPROPRIATE METHOD OF \\ SUPPLY CHAIN OPERATIONN REFERENCE (SCOR)
}

\author{
Arief Rakhman*)1, Machfud"*), dan Yandra Arkeman**) \\ *) PT Indokarlo Perkasa \\ Jl. Raya Bogor No.507, Nanggewer Mekar, Cibinong, Bogor 16912 \\ **) Departemen Teknologi Industri Pertanian, Fakultas Teknologi Pertanian, Institut Pertanian Bogor \\ Jl. Kamper, Wing 4 Level 5 Kampus IPB Darmaga, Bogor 16680
}

\begin{abstract}
Business competition in the automotive world is increasingly hypercompetitive. According to the Motor Vehicle Industry Association, annual purchase of motor vehicles has increased the share of automotive business. However, this increasingly open business condition has not been followed by positive impacts on the corporate profits of PT. XYZ in a span of 5 years. This study measured the performance of the supply chain in PT. XYZ using SCOR model approach. The weighting was calculated using fuzzy AHP and performance assessment matrix. The improved supply chain performance was formulated with the method of Focus Group Discussion (FGD). The measurement results show that the performance of supply chain in PT. XYZ is in the Good category (76\%), the effectiveness performance with a value of $85 \%$ is in Good category while the efficiency performance is in Average category (68\%). Supply chain improvement strategy was formulated with 3 tools: campaign quality, shop floor management, and cost control.
\end{abstract}

Keywords: performance appraisal, SCOR, FGD, Fuzzy AHP

\begin{abstract}
Abstrak: Tujuan penelitian ini adalah untuk menganalisis struktur rantai pasok di PT. XYZ, mengukur kinerja rantai pasok, dan merancang solusi untuk meningkatkan kinerja rantai pasok PT. XYZ. Metode penelitian dengan menggunakan pendekatan model SCOR, Pembobotan dihitung dengan menggunakan fuzzy AHP, dan penilaian matrik kinerja serat Focus Group Discussion (FGD). Struktur rantai pasok di PT. XYZ dikategorikan sebagai extended supply chain merupakan struktur rantai pasok yang ideal bagi perusahaan dengan kemitraan jangka pendek. Pelaku rantai pasok di PT. XYZ terdiri dari supplier, subcont submaterial, PT. XYZ, subcont jasa finishing, customer OEM, customer simplifikasi, customer export, dan customer after market. Hasil dari pengukuran pada level atribut kinerja adalah Reliabilitas (92\% Excellent), Responsivitas (70\% - Average), Fleksibilitas (71\% Good), Biaya ( $71 \%$ - Good), dan Asset $(60 \%$ - Average). Dalam meningkatkan kinerja rantai pasok di PT. XYZ harus dilakukan dengan 3 tools improve yaitu, quality campaign, improvement shopfloor, dan cost control manajemen.
\end{abstract}

Kata kunci: penilaian kinerja, SCOR, FGD, Fuzzy AHP

\footnotetext{
${ }^{1}$ Alamat Korespondensi:

Email: rahman_arh06091@yahoo.co.id
} 


\section{PENDAHULUAN}

Pada era globalisasi ini, zaman sudah semakin hiperkompetitif. Perusahan dituntut untuk memiliki value yang dapat memenuhi harapan customer. Penelitian ekonomi Center of Reform on Economics (CORE) Indonesia menyatakan bahwa industri otomotif adalah sektor yang potensial yang harus dikembangkan oleh pemerintahan Indonesia karena mampu menyerap tenaga kerja yang banyak. Setiap tahunnya pembelian kendaraan mengalami kenaikan seperti yang digambarkan pada Gambar 1.

Seiring dengan semakin pesatnya pertumbuhan industri kendaraan bermotor dunia, maka akan mendorong pertumbuhan industri komponen kendaraan bermotor sebagai penyokong industri tersebut. Keberadaan produksi komponen kendaraan bermotor tersebut, di samping untuk memasok ke pabrikan mobil atau Original Equipment Manufacturer (OEM), juga untuk memenuhi kebutuhan konsumen (after market), baik di pasar domestik maupun internasional.

PT. XYZ merupakan salah satu perusahaan otomotif yang bergerak dalam penyediaan rubber part ke perusahaan-perusahaan Agen Tunggal Pemegang Merk (ATPM), after market dan industri non otomotif. Dalam perjalanannya sebagai partner perusahaan otomotif sudah selayaknya peningkatan kemajuan industri otomotif akan sejalan dengan kemajuan PT. XYZ. Namun, dalam kurun waktu 5 tahun terakhir Net Income PT. XYZ mengalami grafik penurunan (Gambar 2). Hal ini menjadi bahasan yang menarik untuk dianalisis dan dikembangkan dari sisi aktivitas operasional bisnis yang meliputi aktivitas supply chain management atau manajemen rantai pasok.
Menurut Anatan dan Lena (2008), manajemen rantai pasok merupakan strategi alternatif yang memberikan solusi dalam menghadapi ketidakpastian lingkungan untuk mencapai keunggulan kompetitif melalui pengurangan biaya operasi dan perbaikan pelayanan konsumen dan kepuasan konsumen. Selain itu tujuan utama perusahaan adalah mencapai laba optimum guna memaksimalkan nilai para pemegang saham dan kesejahteraan stakeholder perusahaan. Untuk mencapai hal tersebut perusahaan harus meningkatkan kinerjanya dengan cara mengelola aktivitas bisnisnya secara efektif, efisien, dan ekonomis (Copra dan Maindel, 2007).

Meningkatkan daya saing perusahaan dalam bentuk efektivitas dan efisiensi produktivitas telah menjadi suatu hal terpenting dimana mutu produk dan pelayanan juga merupakan faktor utama yang memengaruhi kepuasan pelanggan guna kelangsungan hidup perusahaan. Peningkatan efisiensi, salah satunya dapat dilakukan dengan integrasi kegiatan rantai pasok perusahaan, agar tidak terjadi kesulitan dalam proses perencanaan operasional rantai pasok (Heizer dan Render, 2008).

Mentzer et al. (2001) mendefinisikan rantai pasok sebagai serangkaian entitas yang terdiri atas tiga atau lebih entitas (baik individu maupun organisasi) yang terlibat secara langsung dari hulu ke hilir dalam aliran produk, jasa, keuangan, dan/atau informasi dari sumber kepada pelanggan. Definisi lain menurut APICS (American Production and Inventory Control Society) dictionary yang dikutip oleh Fredenhall and Hill (2001), supply chain adalah rangkaian proses dari bahan-bahan baku menuju konsumsi akhir produk jadi yang terhubung antara pemasok dan perusahaan.

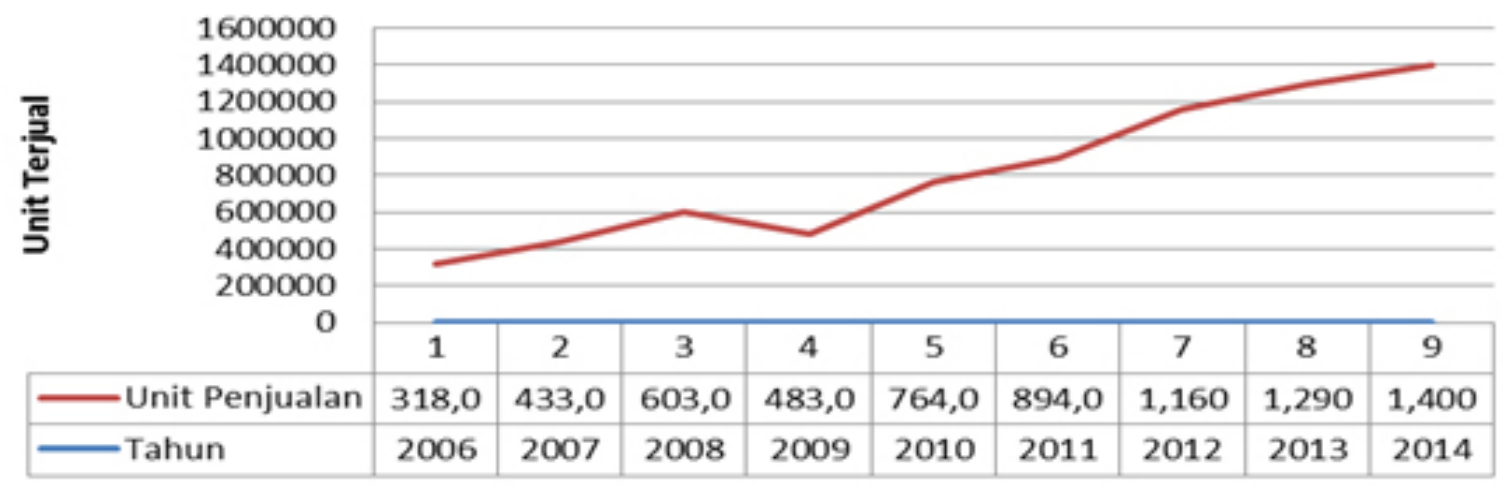

Gambar 1. Grafik Penjualan kendaraan periode 2006-2014 (Gaikindo, 2014) 


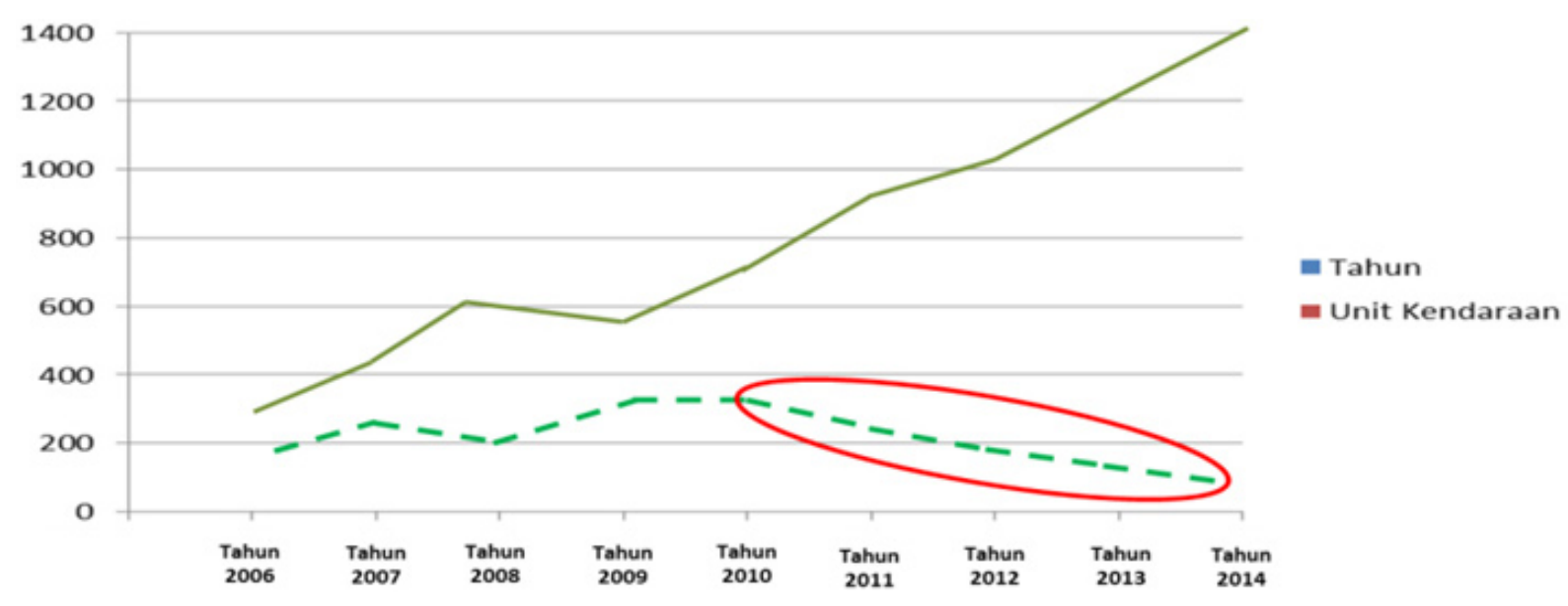

Gambar 2. Grafik trend laba perusahaan vs unit kendaraan terjual

Salah satu model pengukuran kinerja rantai pasok adalah SCOR (Supply Chain Operations Reference) yang dikembangkan oleh Supply Chain Council. SCOR merupakan suatu metode sistematis yang mengombinasikan unsur-unsur seperti teknik bisnis, benchmarking, dan praktek terbaik (best practice) untuk diterapkan dalam rantai pasokan yang diwujudkan ke dalam suatu kerangka kerja yang komprehensif sebagai referensi untuk meningkatkan kinerja rantai pasokan perusahaan tertentu (Marimin dan Maghfiroh, 2010).

Penelitian mengenai penilaian kinerja rantai pasok dengan menggunakan pendekatan SCOR telah banyak dilakukan oleh beberapa peneliti, diantaranya: Setiawan et al. (2011); Hanugrani (2008); Sumiati (2006); Satyanegara (2012); Mutakin dan Hubeis (2011); Mardhiyah (2008). Namun, perbedaan pada kajian penelitian ini, perancangan metode pengukuran kinerja mengkombinasikan model SCOR sebagai perancangan matrik pengukuran kinerja dengan fuzzy AHP sebagai penentuan bobotnya dan benchmark terhadap perusahaan yang direkomendasikan dari tempat dilakukan penelitian. Selain itu, objek penelitian yaitu perusahaan otomotif dalam skala industri belum pernah dilakukan oleh peneliti lain.

Berdasarkan kondisi perusahaan dari sisi net income dibandingkan dengan perkembangan bisnis automotive dalam rentang lima tahun terkahir, maka peneliti melakukan kajian analisis kinerja manajemen rantai pasok dengan menggunakan pendekatan metode SCOR Di PT. XYZ. Tujuan penelitian ini adalah untuk menganalisis struktur rantai pasok di PT. XYZ, mengukur kinerja rantai pasok, dan merancang solusi untuk meningkatkan kinerja rantai pasok PT. XYZ.

\section{METODE PENELITIAN}

Pengumpulan data dilakukan dengan beberapa cara, yaitu (1) Studi literatur, terutama mengenai proses produksi PT. XYZ dan Supply Chain Management (SCM); (2) Survei langsung lapangan ke PT. XYZ dengan mempelajari berbagai dokumen tentang proses produksi, saluran distribusi (termasuk mekanisme supply chain yang berlaku), aktivitas jual beli PT. XYZ, dan semua aspek pendukungnya; (3) Wawancara dengan pihak-pihak yang terlibat dalam supply chain yang telah berjalan di Industri PT. XYZ, serta kesediaannya untuk berpartisipasi dalam penelitian ini; (4) Opini pakar yang diperoleh dari para pakar yang terkait dengan topik penelitian.

\section{Analisis Kondisi Rantai Pasok}

Analisis kondisi rantai pasok dianalisis dengan menggunakan metode deskriptif mengikuti kerangka proses yang didefinisikan oleh Van der Vorst (2005) dapat dilihat pada Gambar 3.

Analisis Pengukuran Kinerja Rantai Pasok

Perancangan metode pengukuran kinerja mengacu kepada permodelan SCOR yang mencakup atribut kinerja customer facing (efektivitas) dan internal facing (effisiensi) (Setiawan et al. 2009). Penggunaan model SCOR dalam merancang system pengukuran kinerja rantai pasok berdasarkan proses, membuat perusahaan mampu mengevaluasi kinerja rantai pasok secara holistic untuk melakukan monitoring dan pengendalian, mengkomunikasikan tujuan organisasi ke fungsifungsi pada rantai pasok dan mengetahui dimana posisi dimana suatu organisasi relative terhadap pesaing, 
serta menentukan arahan perbaikan bagi penciptaan keunggulan bersaing (Mutakin dan Hubeis, 2011). Aramyan et al. (2006), menyatakan bahwa SCOR model memiliki kelebihan mampu menilai kinerja secara keseluruhan dari rantai pasok dalam berbagai dimensi.

Untuk menghitung kinerja rantai pasok dilakukan perancangan hirerarki dan pembobotan dengan fuzzy AHP. Penggunaan teknik logika fuzzy untuk mendapatkan hasil yang relevan dari data yang ambigu dari proses kognitif manusia (Ayag dan Ozdemir, 2006). Penilaian kinerja dimulai dari matrik penilaian kinerja sesuai dengan kartu SCOR pada Tabel 1.

Indikator penilaian yang disediakan dalam model SCOR untuk mengukur kinerja proses rantai pasok (Bolstroff dan Rosenbaum, 2003) dinyatakan dalam ukuran kuantitatif yang disebut matriks-matriks penilaian. Fungsi dari indikator ukuran kuantitatif adalah agar kinerja rantai pasok dapat diukur dengan baik, dapat menentukan target peningkatan yang dikehendaki dan dapat dievaluasi mengenai besarnya peningkatan kinerja rantai pasok yang ingin dicapai (Gunasekaran et al. 2001). Hasil penilaian matrik kinerja dilakukan perhitungan terhadap bobot AHP fuzzy sehingga diperoleh kinerja terbobot pada setiap level matrik penilaian kinerja. Pada akhir perhitungan dapat diperoleh penilaian kinerja PT. XYZ secara keseluruhan. Indikator kinerja dapat dikategorikan ke dalam kriteria poor, marginal, average, Good, atau Excellent berdasarkan Tabel 2.

\section{Perumususan Strategi Peningkatan Kinerja Rantai Pasok}

Perumusan strategi peningkatan kinerja menggunakan metode Focus Group Discusion (FGD) dengan manajemen PT. XYZ yang terdiri dari berbagai departemen terkait yang berhubungan dengan aktivitas rantai pasok.

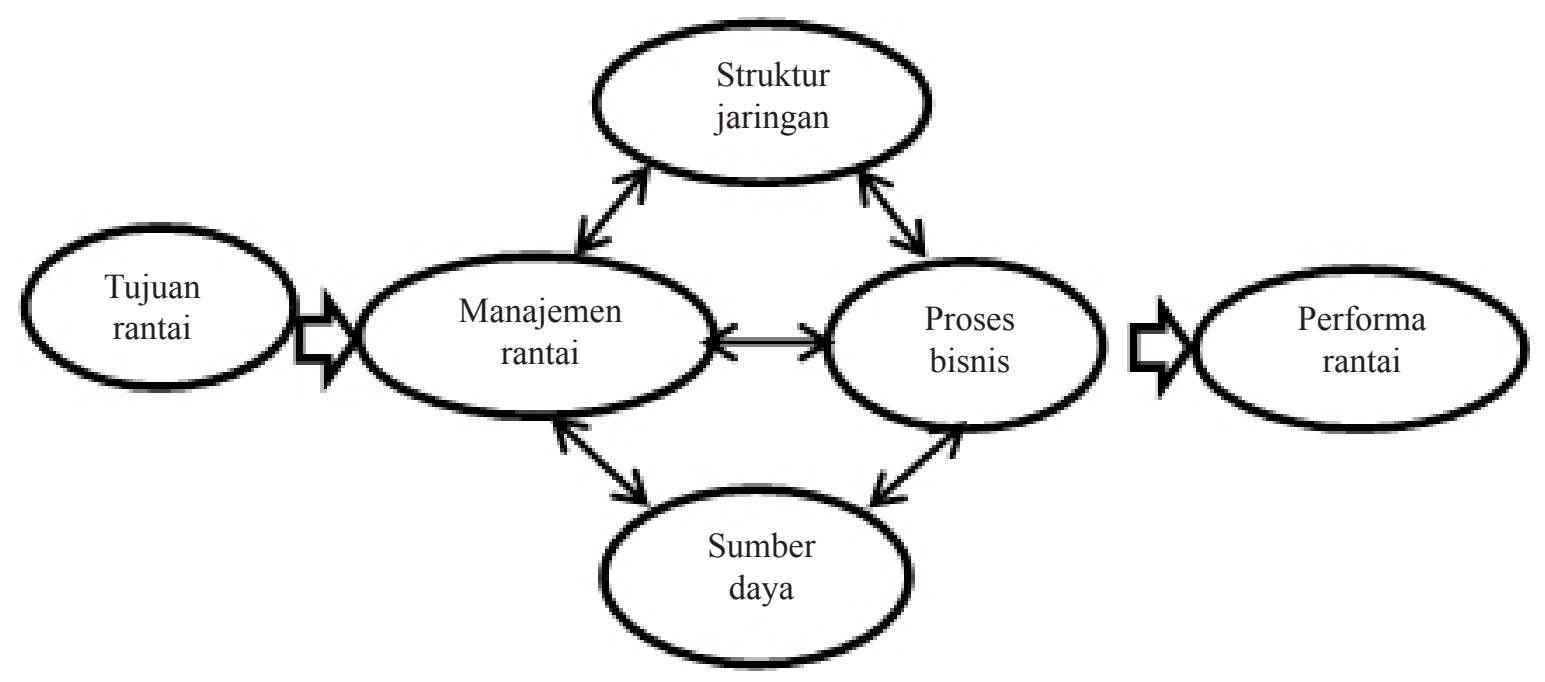

Gambar 3. Kerangka analisis manajemen rantai pasok (Van der Vorst, 2005)

Tabel 1. Kartu SCOR

\begin{tabular}{llll}
\hline \multicolumn{1}{c}{ Atribut kinerja } & \multicolumn{1}{c}{ Matrik pengukuran kinerja } & Data aktual & Data benchmark \\
\hline Supply chain reliability & Pemenuhan Pesanan (PP) & $\%$ & $\%$ \\
& Kinerja Pengiriman (KP) & $\%$ & $\%$ \\
& Kesesuaian dengan Standard Mutu (KS) & $\%$ & $\%$ \\
Supply chain responsiveness & Siklus Pemenuhan Pesanan (SPP) & Hari & Hari \\
& Lead Time Pemenuhan Pesanan (LTPP) & Hari & Hari \\
Supply chain flexibility & Fleksibilitas Rantai Pasok (FP) & Hari & Hari \\
Supply chain cost & Biaya Supply Chain (BSCM) & Rp & Rp \\
Supply chain asset & Siklus Cash to Cash (SCTC) & Hari & Hari \\
& Persediaan Harian (PH) & Hari & Hari \\
\hline
\end{tabular}


Tabel 2. Skala system monitoring kinerja

\begin{tabular}{lc}
\hline \multicolumn{1}{c}{ Sistem monitoring } & Indikator kinerja \\
\hline$<40 \%$ & Poor \\
$40-50 \%$ & Marginal \\
$50-70 \%$ & Average \\
$70-90 \%$ & Good \\
$>90 \%$ & Excellent \\
\hline
\end{tabular}

Kerangka penelitian ini dirumuskan dalam rangka mengidentifikasi struktur rantai pasok, membangun metode pengukuran kinerja rantai pasok, dan merancang strategi perumusan untuk meningkatkan kinerja rantai pasok. Analisis kondisi rantai pasok dilakukan untuk mengidentifikasi analisis struktur dan pelaku rantai pasok. Perancangan metode pengukuran kinerja dibangun dengan mengidentifikasi matrik kinerja dan penentuan bobot matrik pengukuran kinerja. Selanjutnya dilakukan impelementasi dan integrasi penilaian metode pengukuran kinerja rantai pasok dan perumusan strategi peningkatan kinerja rantai pasok. Kerangka pemikiran dapat dilihat pada Gambar 4.

\section{HASIL}

\section{Analisis Struktur dan Pelaku Rantai Pasok}

Teori Hugos (2003), strukur rantai pasok PT. PT. XYZ merupakan Extended Supply Chain dimana terdapat beberapa pelaku rantai pasok yang saling mendukung untuk menjalankan kegiatan rantai pasoknya. Struktur Rantai Pasok PT. XYZ dapat digambarkan seperti Gambar 5.

Struktur rantai pasok PT. XYZ yang secara langsung berhubungan digambarkan pada Gambar 5 dengan batasan garis putus-putus. PT. XYZ telah menerapkan system multi source suplier yang dianggap lebih ideal dengan kondisi kemitraan yang ada. Selain itu beberapa proses pendukung seperti finishing PT. XYZ melakukan proses subcont yang dapat mengurangi beban perusahaan.

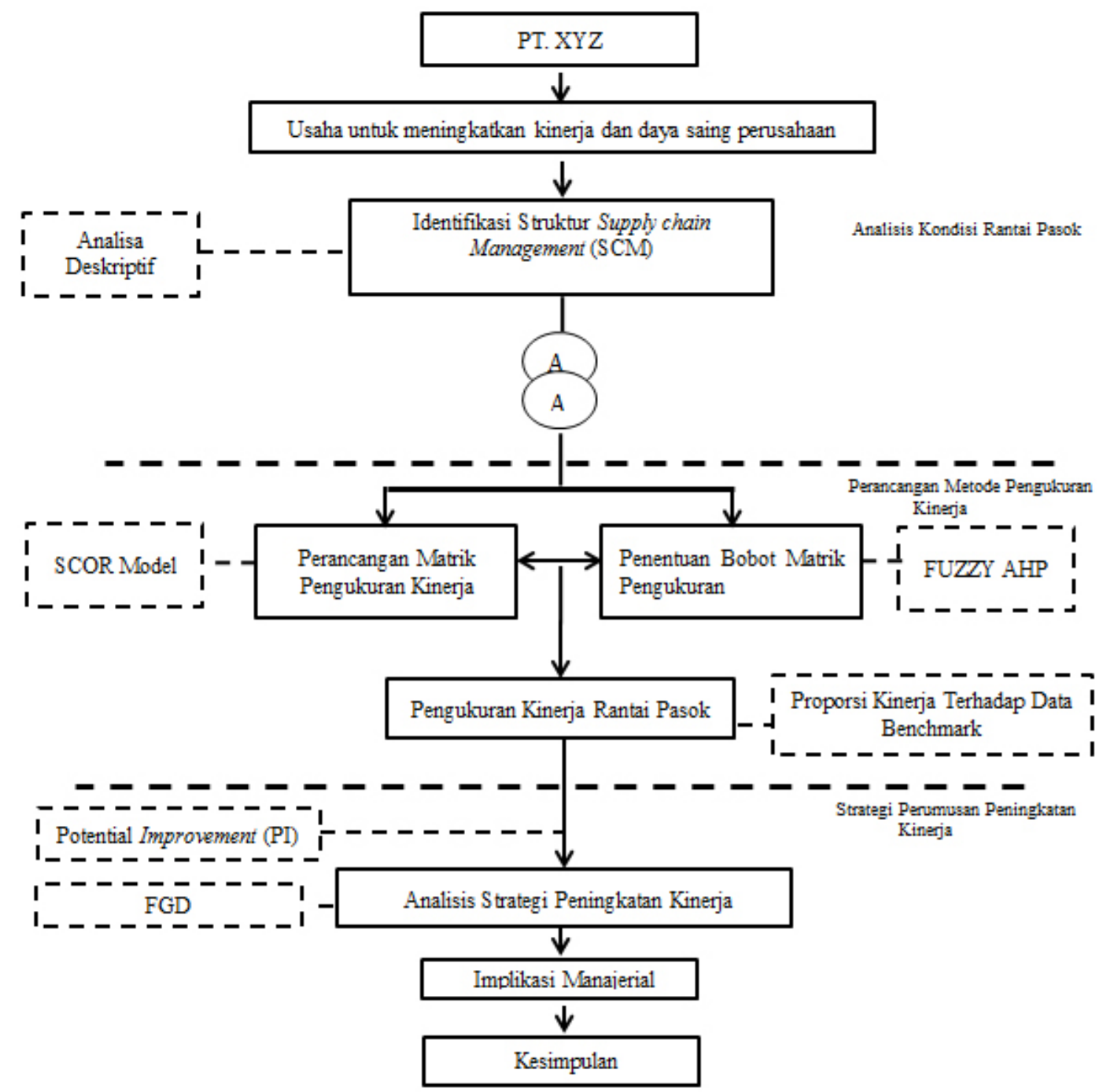

Gambar 4. Kerangka Pemikiran Penelitian 


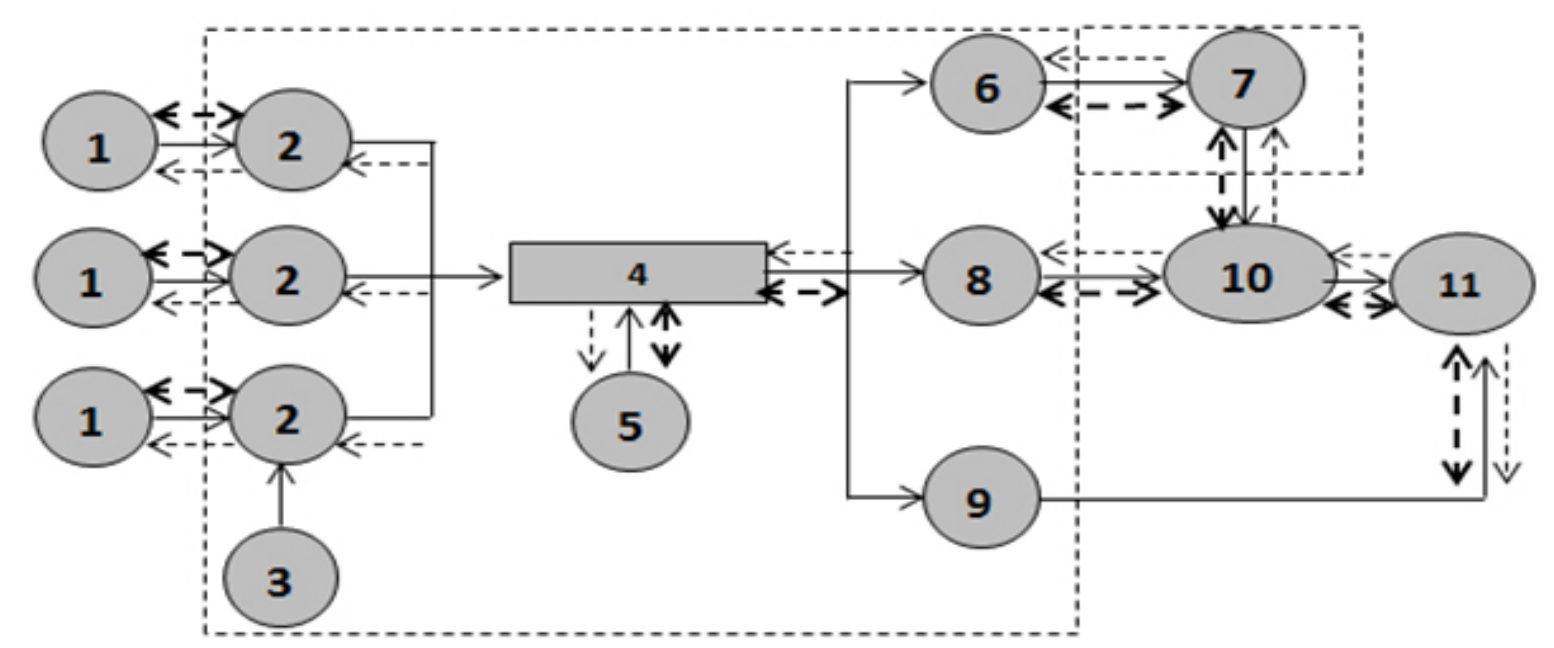

Gambar 5. Struktur rantai pasok PT. XYZ (1. Secondtier; 2. Suplier; 3. Subcont Sub Material; 4. PT.XYZ; 5. Subcont Jasa Finishing; 6. Customer Simplifikasi; 7. Customer OEM; 8. Customer Export; 9. Customer After Market; 10. Dealer; 11. Customer akhir; $\rightarrow$ Aliran barang; $-\rightarrow$ Alirang Uang; $<->$ Aliran Informasi)

\section{Analisis Kinerja Rantai Pasok}

Berdasarkan sistem matrik kinerja SCOR pada pemetaan level 1 dibagi dalam 2 aspek utama, yaitu Efektivitas (Customer Facing) untuk mengukur atribut kinerja rantai pasok Reliability, Responsiveness, dan flexibility terhadap pelanggan dan pemasok. Selanjutnya, Effisiensi (Internal Facing) untuk mengukur biaya rantai pasok dan effisiensi manajemen asset. Di samping itu, hasil wawancara dengan manajemen PT. XYZ disebutkan bahwa tujuan perusahaan didefinisikan memberikan tingkat pelayanan terbaik pada pelanggan dan meningkatkan keuntungan perusahaan

Hasil perhitungan terhadap matrik pengukuran kinerja di PT. XYZ dapat dibandingkan terhadap data benchmark. Data benchmark diambil dari perusahaan sejenis PT. XYZ dengan core bisnis yang sama. Data perbandingan kinerja PT. XYZ dengan data kinerja PT. ABC sebagai benchmark disajikan dalam Tabel 3.

Kinerja PT. XYZ dibandingkan dengan data benchmark untuk kriteria Excellent adalah Pemenuhan Pesanan (PP) dan Kinerja Pengiriman (KP). Sedangkan untuk kategori Good adalah kriteria Flekibilitas Pasokan (FP), Biaya SCM, dan Siklus Cash to Cash Cycle (SCTC). Untuk kategori average adalah kinerja Siklus Pemenuhan Pesanan (SPP) dan Lead Time Pemenuhan Pesanan (LTPP). Untuk kategori kinerja Poor adalah Kesesuan dengan Standar mutu (KS) dan Persediaan Harian (PH).
Kriteria mutu memiliki persentase kinerja sebesar 43\% terhadap data benchmark. Kesesuaian Mutu PT. XYZ diakibatkan oleh proses produksi yang menggunakan system subcont atau jasa untuk proses finishing atau assy. Sehingga kesadaran akan mutu harus ditingkatkan pada setiap level proses dari internal, subcont, sampai produk terkirim ke pelanggan. Peningkatan kesadaran mutu PT. XYZ dilakukan dengan metode training berjenjang dari level operator hingga pimpinan kerja.

Kriteria lain yang memerlukan aktivitas improvement adalah persediaan harian, dimana kondisi persediaan dapat dikatakan berlebih pada setiap Work in Proccess (WIP). Stock WIP yang berlebih diakibatkan oleh perencanaan produksi yang tidak tepat, akurasi stock yang tidak baik, dan pengelolaan persediaan yang tidak baik. Kondisi ini menyebabkan ineffisiensi karena memerlukan energi berlebih untuk mengelola persediaan. Persediaan yang berlebihan juga dapat diterjemahkan menjadi asset yang tidak bergerak sehingga mengganggu cash flow perusahaan.

\section{Pembobotan dengan AHP Fuzzy}

Untuk menentukan tingkat kepentingan, maka dilakukan perhitungan AHP Fuzzy dengan design hierarki permodelan SCOR pada Gambar 6. Pada level parameter kinerja efektivitas memiliki bobot 0,4568 sedangkan effisiensi memiliki bobot 0,5432 Effisiensi memiliki bobot lebih besar dari pada efektivitas menunjukan bahwa effisiensi lebih prioritas daripada efektivitas. Dengan varian produk yang 
tinggi dan lead time proses yang berbeda-beda internal effisiensi merupakan tuntutan parameter kinerja untuk memenangkan persaingan dengan kompetitor.

Pada level atribut kinerja terhadap efektivitas, reliabilitas memiliki bobot 0,6479 , responsivitas memiliki bobot 0,2061 , dan fleksibilitas memiliki bobot 0,1460 . Faktor reliabilitas atau kepercayaan pelanggan merupakan prioritas utama yang harus dipenuhi oleh improvement hal ini ditunjukan dengan nilai bobot yang dominan dari atribut kinerja lainnya. Reliabilitas meliputi kinerja pengiriman, pemenuhan pesananan, dan kesesuaian dengan standar mutu.

Pada level atribut kinerja terhadap effisiensi, biaya memiliki bobot 0,7060 sedangkan asset memiliki bobot 0,2940 . Hal ini menunjukan bahwa biaya merupakan faktor penting dalam menunjukan performa effisiensi. Biaya yang dimaksud mencakup biaya rantai pasok dari mulai proses perencanaan (plan), pengadaan (source), produksi (make), pengiriman (delivery), dan pengembalian (return).

Pada level matrik pengukuran kinerja terhadap reliabilitas pada level atribut kinerja Kinerja Pengiriman (KP) memiliki bobot 0,5735, Pemenuhan Pesanan (PP) memiliki bobot 0,3029 , sedangkan Kesesuaian dengan Standar mutu (KS) memiliki bobot 0,1236. Kinerja pengiriman merupakan prioritas yang harus dipenuhi, diikuti dengan pemenuhan pesanan dan kesesuaian dengan standar mutu.

Pada level matrik pengukuran kinerja terhadap responsivitas pada level atribut kinerja, siklus pemenuhan pesanan (SPP) memiliki bobot 0,4568 sedangkan lead time pemenuhan pesanan (LTPP) memiliki bobot 0,5432. Hal ini menunjukan LTPP merupakan prioritas matrik kinerja yang harus dipenuhi oleh PT. XYZ.

Tabel 3. Hasil perhitungan matrik kinerja PT. XYZ

\begin{tabular}{lcccc}
\hline \multicolumn{1}{c}{ Matrik kinerja } & Kinerja PT. XYZ & Banchmark & Nilai kinerja & Indikator kinerja \\
\hline Pemenuhan Pesanan (PP) & $99 \%$ & $100 \%$ & $99 \%$ & Excellent \\
Kinerja Pengiriman (KP) & $99 \%$ & $100 \%$ & $99 \%$ & Excellent \\
Kesesuaian dengan standar mutu (KS) & $2,3 \%$ & $100 \%$ & $43 \%$ & Poor \\
Siklus Pemenuhan Pesanan (SPP) & 20 hari & 14 hari & $70 \%$ & Average \\
Lead Time Pemenuhan Pesanan (LTPP) & 10 hari & 7 hari & $70 \%$ & Average \\
Fleksibilitas Pasokan (FP) & 5 hari & 7 hari & $71 \%$ & Good \\
Biaya SCM & Rp14.000 & Rp 10.000 & $71 \%$ & Good \\
Siklus Cash to Cash Cycle (SCTC) & 30 hari & 21 hari & $70 \%$ & Average \\
Persediaan Harian (PH) & 48,9 hari & 21 hari & $43 \%$ & Poor \\
\hline
\end{tabular}

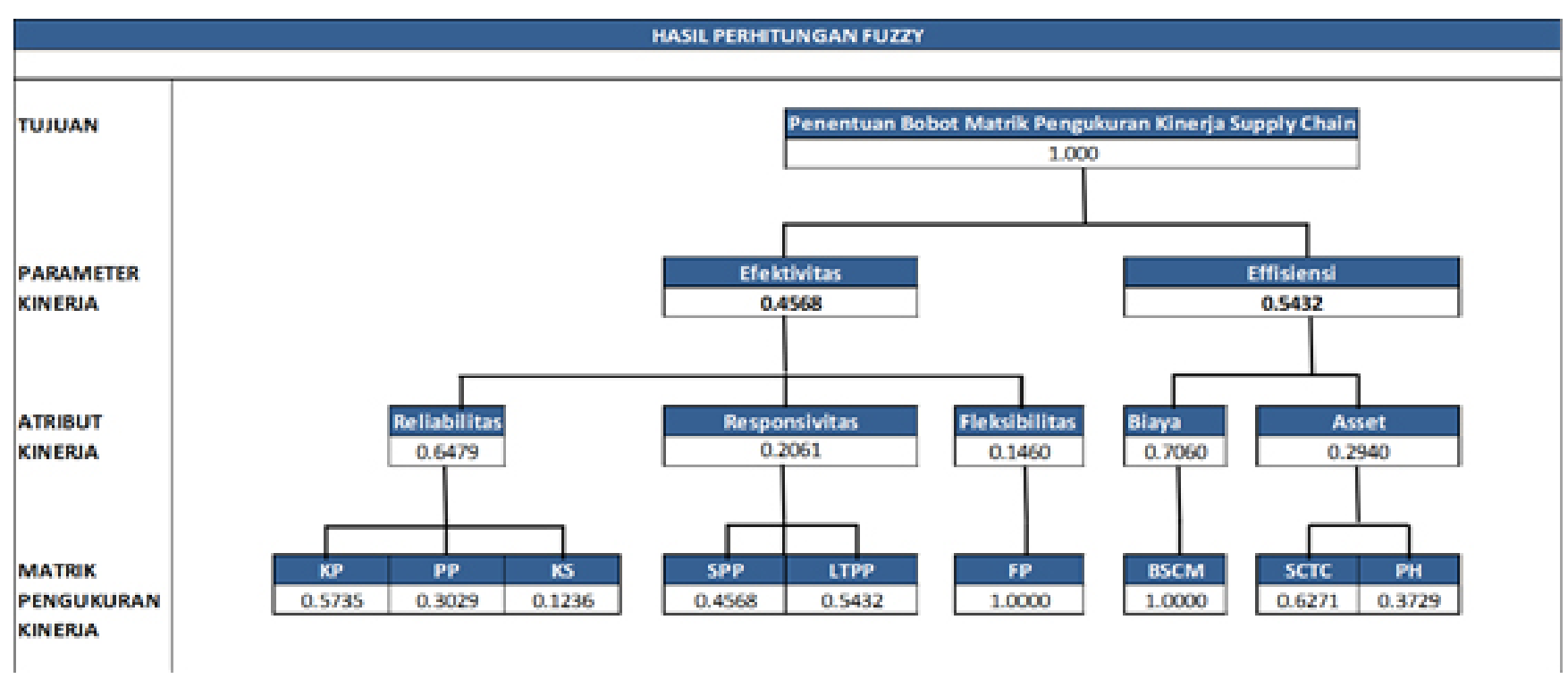

Gambar 6. Hasil pembobotan dengan AHP Fuzzy 
Matrik kinerja fleksibilitas pasokan dan biaya supply chain terhadap fleksibilitas dan biaya merupakan faktor mutlak dari masing-masing atribut kinerja. Masingmasing bobot pada matrik tersebut memiliki nilai 1 . Fleksibilitas pasokan merupakan kesiapan perusahaan dalam memenuhi peningkatan atau penurunan order dari sisi source, make, dan delivery. Biaya meliputi biaya rantai pasok yang terdiri dari biaya perencanaan, biaya pengadaan, biaya produksi, biaya pengiriman, dan biaya pengembalian.

Pada level matrik pengukuran kinerja terhadap asset pada level atribut kinerja siklus cash to cash cycle (SCTC) memiliki bobot 0,6271 , sedangkan persediaan harian memiliki bobot 0,3729 . Hal ini menunjukan bahwa SCTC merupakan aktvitas prioritas yang harus dilakukan monitoring berkaitan dengan kinerja asset.

\section{Pengukuran Kinerja PT. XYZ}

Kinerja PT. XYZ pada level parameter kinerja dapat dihitung dengan menggabungkan perhitungan bobot AHP fuzzy terhadap kinerja matrik dibawanya. Nilai kinerja dan kinerja terbobot pada level matrik kinerja pada Tabel 4. Berdasarkan Tabel 4 dapat dilihat bahwa matrik kinerja Persediaan Harian dan Kesesuaian dengan standar mutu memiliki kinerja pada level poor. Sedangkan siklus pemenuhan pesanan, lead time pemenuhan pesanan, dan siklus cash to cash cycle memiliki kinerja average. Fleksibilitas pasokan dan Biaya rantai pasok memiliki kinerja good, sedangkan pemenuhan pesanan dan kinerja pengiriman memiliki kinerja excellent.

Dari bobot kinerja pada level matrik pengukuran kinerja yang telah diketahui maka dapat dilakukan perhitungan nilai kinerja pada level atribut kinerja sebagaimana tersaji pada Tabel 5. Berdasarkan Tabel 5 dapat dijelaskan bahwa atribut kinerja responsivitas dan asset memiliki kinerja average, sedangkan fleksibilitas dan biaya memiliki nilai kinerja good. Atribut kinerja reliabilitas yang dipengaruhi oleh kinerja pengiriman dan pemenuhan pesanan memiliki nilai kinerja excellent.

Dari bobot kinerja pada level atribut kinerja yang telah diketahui maka dapat dilakukan perhitungan nilai kinerja pada level parameter kinerja sebagaimana tersaji pada Tabel 6. Berdasarkan Tabel 6 dapat dilihat bahwa parameter kinerja efektivitas memiliki nilai kinerja $85 \%$ dengan indikator kinerja good. Effisiensi memiliki nilai kinerja $68 \%$ dengan indikator kinerja average. Parameter efektivitas dipengaruhi oleh atribut kinerja reliabilitas, responsivitas, dan fleksibilitas rantai pasok. Sebaliknya, parameter effisiensi dipengaruhi oleh atribut kinerja biaya dan asset.

Tabel 4, Bobot kinerja berdasarkan nilai kinerja dan nilai bobot pada level matrik kinerja

\begin{tabular}{lcccc}
\hline \multicolumn{1}{c}{ Matrik kinerja } & Nilai kinerja & Indikator kinerja & Nilai bobot & Kinerja terbobot \\
\hline Pemenuhan Pesanan (PP) & $99 \%$ & Excellent & 0,573 & 0,57 \\
Kinerja Pengiriman (KP) & $99 \%$ & Excellent & 0,303 & 0,30 \\
Kesesuaian dengan standar mutu (KS) & $43 \%$ & Poor & 0,124 & 0,05 \\
Siklus Pemenuhan Pesanan (SPP) & $70 \%$ & Average & 0,457 & 0,32 \\
Lead Time Pemenuhan Pesanan (LTPP) & $70 \%$ & Average & 0,543 & 0,38 \\
Fleksibilitas Pasokan (FP) & $71 \%$ & Good & 1,000 & 0,71 \\
Biaya SCM & $71 \%$ & Good & 1,000 & 0,71 \\
Siklus Cash to Cash Cycle (SCTC) & $70 \%$ & Average & 0,627 & 0,44 \\
Persediaan Harian (PH) & $43 \%$ & Poor & 0,373 & 0,16 \\
\hline
\end{tabular}

Tabel 5. Bobot kinerja berdasarkan nilai kinerja dan nilai bobot pada level atribut kinerja

\begin{tabular}{lcccc}
\hline \multicolumn{1}{c}{ Atribut kinerja } & Nilai kinerja & Nilai bobot & Indikator kinerja & Kinerja terbobot \\
\hline Reliabilitas & $92 \%$ & 0,6479 & Excellent & 0,60 \\
Responsivitas & $70 \%$ & 0,2061 & Average & 0,14 \\
Fleksibilitas & $71 \%$ & 0,1460 & Good & 0,10 \\
Biaya & $71 \%$ & 0,7060 & Good & 0,50 \\
Asset & $60 \%$ & 0,2940 & Average & 0,18 \\
\hline
\end{tabular}


Dari bobot kinerja pada level parameter kinerja yang telah diketahui maka dapat dilakukan perhitungan nilai kinerja pada level tujuan, yaitu kinerja rantai pasok secara keseluruhan pada PT. XYZ. Berdasarkan Tabel 7 dapat diperoleh angka bahwa kinerja PT. XYZ secara keseluruhan adalah $76 \%$ atau dalam level good. Kinerja rantai pasok dipengaruhi oleh efektivitas dan effisinsi pada level parameter kinerja. Hal ini menunjukan bahwa PT XYZ memerlukan perbaikan pada beberapa level terutama yang berkaitan dengan internal effisiensi agar mampu bersaing pada industri otomotif dunia.

\section{Evaluasi dan Perbaikan Rantai Pasok}

Berdasarkan permasalahan penilaian kinerja dari sisi efektivitas dan effisiensi dilakukan pencarian solusi melalui metode forum group discussion (FGD) dengan manajemen PT. XYZ. Hasil FGD untuk meningkatkan kinerja rantai pasok PT dapat dijabarkan pada Tabel 8.

Tabel 6. Bobot kinerja berdasarkan nilai kinerja dan nilai bobot pada level parameter kinerja

\begin{tabular}{lcccc}
\hline \multicolumn{1}{c}{ Parameter kinerja } & Nilai kinerja & Nilai bobot & Indikator kinerja & Kinerja terbobot \\
\hline Efektivitas & $85 \%$ & 0,4568 & Good & $39 \%$ \\
Effisiensi & $68 \%$ & 0,5432 & Average & $37 \%$ \\
\hline
\end{tabular}

Tabel 7. Nilai kinerja pada level tujuan

\begin{tabular}{ccc}
\hline Atribut kinerja & Nilai kinerja & Indikator kinerja \\
\hline Kinerja SCM PT. XYZ & $76 \%$ & Good \\
\hline
\end{tabular}

Tabel 8. Analisis Perbaikan terhadap nilai kinerja PT. XYZ

\begin{tabular}{|c|c|c|c|c|c|c|}
\hline \multicolumn{2}{|c|}{ Parameter kinerja } & \multicolumn{2}{|l|}{ Atribut kinerja } & \multicolumn{2}{|l|}{ Matrik kinerja } & \multirow{2}{*}{$\begin{array}{l}\text { Tools improve } \\
\text { Shopfloor } \\
\text { Manajemen }\end{array}$} \\
\hline Efektivitas & $\begin{array}{l}\text { Good } \\
(85 \%)\end{array}$ & Reliabilitas & $\begin{array}{l}\text { Excellent } \\
(92 \%)\end{array}$ & Pemenuhan Pesanan (PP) & $\begin{array}{l}\text { Excellent } \\
(99 \%)\end{array}$ & \\
\hline & & & & Kinerja Pengiriman (KP) & $\begin{array}{l}\text { Excellent } \\
(99 \%)\end{array}$ & $\begin{array}{l}\text { Shopfloor } \\
\text { Manajemen }\end{array}$ \\
\hline & & & & $\begin{array}{l}\text { Kesesuaian dengan standar } \\
\text { mutu (KS) }\end{array}$ & Poor $(43 \%)$ & $\begin{array}{l}\text { Kampanye Mutu \& } \\
\text { Shopfloor }\end{array}$ \\
\hline & & Responsivitas & $\begin{array}{l}\text { Average } \\
(70 \%)\end{array}$ & $\begin{array}{l}\text { Siklus Pemenuhan Pesanan } \\
\text { (SPP) }\end{array}$ & Average $(70 \%)$ & $\begin{array}{l}\text { Shopfloor } \\
\text { Manajemen }\end{array}$ \\
\hline & & & & $\begin{array}{l}\text { Lead Time Pemenuhan } \\
\text { Pesanan (LTPP) }\end{array}$ & Average $(70 \%)$ & $\begin{array}{l}\text { Shopfloor } \\
\text { Manajemen }\end{array}$ \\
\hline & & Fleksibilitas & $\begin{array}{l}\text { Good } \\
(71 \%)\end{array}$ & Fleksibilitas Pasokan (FP) & Good $(71 \%)$ & $\begin{array}{l}\text { Shopfloor } \\
\text { Manajemen }\end{array}$ \\
\hline \multirow[t]{3}{*}{ Effisiensi } & $\begin{array}{l}\text { Average } \\
(68 \%)\end{array}$ & Biaya & $\begin{array}{l}\text { Good } \\
(71 \%)\end{array}$ & Biaya SCM & Good $(71 \%)$ & Cost Control \\
\hline & & Asset & $\begin{array}{l}\text { Average } \\
(60 \%)\end{array}$ & $\begin{array}{l}\text { Siklus Cash to Cash Cycle } \\
\text { (SCTC) }\end{array}$ & Average $(70 \%)$ & $\begin{array}{l}\text { Cost Control } \\
\& \text { Shopfloor } \\
\text { Manajemen }\end{array}$ \\
\hline & & & & Persediaan Harian (PH) & Poor $(43 \%)$ & $\begin{array}{l}\text { Shopfloor } \\
\text { Manajemen }\end{array}$ \\
\hline
\end{tabular}




\section{Implikasi Manajerial}

Implikasi manajerial atau program aksi yang dilakukan oleh PT. XYZ sesuai dengan tiga tools improve dapat dijabarkan sebagai berikut:

\section{Kampanye mutu}

Kualitas merupakan parameter yang paling penting yang harus dilakukan perbaikan dari masing-masing proses produksi karena memiliki nilai kinerja yang rendah. Tanggung jawab mutu tidak hanya merupakan tanggung jawab departemen quality saja tetapi semua lini proses bertanggung jawab terhadap produk yang dihasilkan. Untuk mendapatkan hasil yang signifikan dalam perbaikan mutu, PT. XYZ membentuk team khusus yang menangani masalah mutu baik yang terjadi di internal (belum terkirim ke customer), maupun yang terjadi di external (sudah terkirim ke customer). Team ini dinamakan sebagai team task force rejection rate. Beberapa aktivitas yang dilakukan adalah room center, periodic review (daily, weekly, monthly), Visual campaign.

\section{Shopfloor Management}

Salah satu yang menjadi fokus perusahaan dalam meningkatkan kenerja dalam ketatnya persaingan bisnis global sekarang ini, para pimpinan perusahaan dituntut agar selalu mengarahkan strateginya tepat sasaran berbasis kaizen dan terfokus pada aspek qualitas (quality, biaya (cost), pengiriman (delivery), dalam sistem penerapan shopfloor manajemen yang terintegrasi di tempat kerja. Flow process di PT. XYZ yang menjadi fokus untuk perbaikan shopfloor sehingga dapat menyelesaikan permasalahan yang berkaitan dengan quality, cost, dan delivery (Gambar 7).

\section{Cost Control}

Biaya merupakan salah satu faktor yang penting dalam sebuah perusahaan. Biaya merupakan alat dasar bagi manajemen dalam melaksanakan fungsi perencanaan, pengawasan, dan pengambilan keputusan. Biaya yang tidak terkontrol akan membuat neraca perusahaan tidak seimbang dan berakibat pada kelangsungan perusahaan.

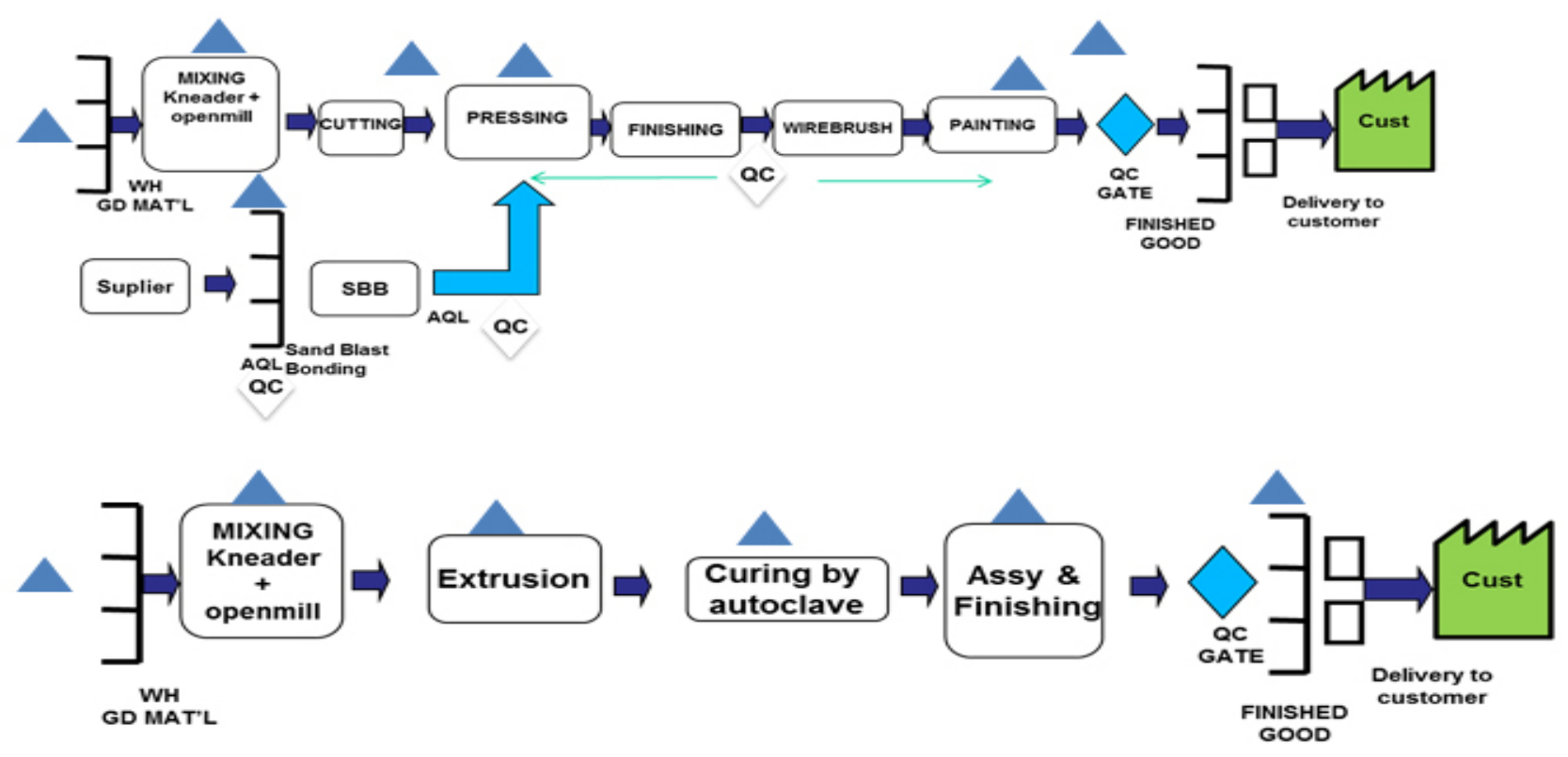

Gambar 7. Mapping area improvement shopfloor di PT. XYZ ( $\Delta$ : area improve) 
Biaya dalam sebuah perusahaan dapat dibedakan berdasarkan fungsinya, yaitu fungsi produksi, fungsi pemasaran, fungsi administrasi umum. Dalam kaitannya dengan pengelolaan biaya di PT. XYZ melakukan aktivitas yang berdampak positif pada neraca keuangan pada Tabel 9.

\section{KESIMPULAN DAN SARAN}

\section{Kesimpulan}

Struktur rantai pasok di PT. XYZ dikategorikan sebagai extended supply chain merupakan struktur rantai pasok yang ideal bagi perusahaan dengan kemitraan jangka pendek. Pelaku rantai pasok di PT. XYZ terdiri dari supplier, subcont submaterial, PT. XYZ, subcont jasa finishing, customer OEM, customer simplifikasi, customer export, dan customer after market. Pelaku rantai pasok PT. XYZ sudah menjalankan kegiatan rantai pasoknya untuk menudukung kegiatan bisnisnya. Pemilihan strategi subcont untuk proses pendukung dianggap sangat baik dalam meminimalisir beban biaya.

Pengukuran kinerja rantai pasok dengan pendekatan model SCOR di PT. XYZ menunjukan hasil sebagai berikut: Pada level matrik kinerja diperoleh hasil Pemenuhan Pesanan $(99 \%=$ Excellent $)$, Kinerja Pengiriman (99\% - Excellent), Kesesuaian dengan
Standar Mutu $(43 \%=$ Poor $)$, Siklus Pemenuhan Pesanan (70\% - Average), Lead Time Pemenuhan Pesanan (70\% - Average), Fleksibilitas Pasokan (71\% Good), Biaya rantai pasok (71\% - Good), Siklus Cash to Cash Cycle (70\% - Average), dan Persediaan Harian (43\% - Poor). Pemenuhan pesanan, kinerja pengiriman, dan kesesuaian dengan standard mutu memengaruhi nilai reliabilitas pada level atribut kinerja, sedangkan siklus pemenuhan pesanan dan lead time pemenuhan pesanan memengaruhi nilai responsivitas. Nilai asset dipengaruhi oleh siklus cash to cash cycle dan persediaan harian. Fleksibilitas pasokan memengaruhi nilai fleksibilitas pada level atribut kinerja, sedangkan biaya rantai pasok memengaruhi nilai kinerja biaya pada level atribut kinerja.

Hasil dari pengukuran pada level atribut kinerja adalah sebagai berikut: Reliabilitas ( $92 \%$ - Excellent), Responsivitas (70\% - Average), Fleksibilitas (71\% Good), Biaya (71\% - Good), dan Asset (60\% - Average). Sedangkan pada level parameter kinerja diperoleh hasil efektivitas ( $85 \%$ - Good) dan effisiensi (68\% - Average). Kinerja rantai pasok secara keseluruhan memiliki nilai kinerja $76 \%$ atau pada indikator kinerja Good. Hasil tersebut menunjukan kinerja yang cukup bagus karena memiliki nilai parameter kinerja efektivitas $(85 \%$ - Good $)$. Akan tetapi, dari sisi effisiensi PT. XYZ memiliki nilai $68 \%$ - Average yang menunjukan diperlukannya perbaikan pada beberapa sektor yang berkaitan dengan effisiensi.

Tabel 9. Activity Cost Control PT. XYZ

\begin{tabular}{|c|c|c|}
\hline Latar Belakang & Target & Activity \\
\hline $\begin{array}{l}\text { Harga jual produk PT. XYZ banyak } \\
\text { yang tidak di update lebih dari } 2 \\
\text { tahun, padahal biaya produksi semakin } \\
\text { meningkat }\end{array}$ & $\begin{array}{l}\text { Harga jual produk PT. XYZ }>3000 \\
\text { rupiah, dan bernilai positif terhadap } \\
\text { COGS actual }\end{array}$ & $\begin{array}{l}\text { - Renegosiation harga ke customer } \\
\text { untuk harga yang selama } 2 \text { tahun } \\
\text { tidak mengalami kenaikan harga } \\
\text { - Evaluasi Cost Of Good Sale (COGS) } \\
\text { untuk produk yang rugi } \\
\text { - Deletion part untuk produk yang } \\
\text { minus lebih dari } 50 \% \text { terhadap actual } \\
\text { COGS }\end{array}$ \\
\hline $\begin{array}{l}\text { PT. XYZ memiliki } 3 \text { gudang external } \\
\text { yang disebabkan karena penumpukan } \\
\text { stock dari mulai stock work in process, } \\
\text { stock finish good, stock raw material, } \\
\text { dan dead stock }\end{array}$ & $\begin{array}{l}\text { Level stock lebih effisien, dan gudang } \\
\text { external dapat di reduce menjadi } 1 \\
\text { gudang }\end{array}$ & $\begin{array}{l}\text { - Monitoring level stock raw material, } \\
\text { wip, dan finish good. } \\
\text { - Beli putus bushing (raw materialnya } \\
\text { adalah pipa) } \\
\text { - Manajemen WIP dengan pembuatan } \\
\text { WH internal WIP }\end{array}$ \\
\hline $\begin{array}{l}\text { Biaya overtime tidak terkendali } \\
\text { padahal loading vs capacity bisa dalam } \\
\text { effisiensi normal cukup }\end{array}$ & $\begin{array}{l}\text { Tidak ada overtime di semua lini } \\
\text { proses }\end{array}$ & $\begin{array}{l}\text { - Balancing capacity internal } \\
\text { - Control productivity } \\
\text { - Control actual over time (target } \\
\text { reduce) }\end{array}$ \\
\hline Biaya armada PT. XYZ tinggi & Kondisi armada di reduce & $\begin{array}{l}\text { - Pengurangan armada melalui } \\
\text { perubahan rute }\end{array}$ \\
\hline
\end{tabular}


Hasil FGD diperoleh kesimpulan bahwa untuk meningkatkan kinerja rantai pasok di PT. XYZ harus dilakukan dengan 3 tools improve yaitu, quality campaign, improvement shopfloor, dan cost control manajemen. Quality campaign dapat meningkatkan kinerja dari sisi kesesuaian dengan standar mutu, sedangkan perbaikan shopfloor manajemen dapat meningkatkan kinerja pemenuhan pesanan, kinerja pengiriman, siklus pemenuhan pesanan, lead time pemenuhan pesanan, fleksibilitas rantai pasok, cash to cash cycle, dan persediaan harian. Cost control manajemen dapat meningkatkan kinerja pada parameter biaya supply chain.

\section{Saran}

Hasil perhitungan menunjukkan PT. Indokarlo Perkasa memiliki kinerja rantai pasok yang cukup bagus, akan tetapi memerlukan perbaikan pada beberapa sektor yang berkaitan dengan internal effisiensi. Selanjutnya, Pelaku rantai pasok PT. Indokarlo Perkasa sudah menjalankan kegiatan rantai pasoknya untuk menudukung kegiatan bisnisnya. Pemilihan strategi subcont untuk proses pendukung dianggap sangat baik dalam meminimalisir beban biaya.

\section{DAFTAR PUSTAKA}

Anatan L, Lena E. 2008. Supply Chain Management Teori dan Aplikasi. Bandung: Alfabeta.

Aramyan LH, Ondersteijn CJM, Kooten O, Oude LAGJM. 2006. Performance indicator in Agrifood production chains. In: Quantifying the agrifood supply chain/Ondersteijn, dr.ir. C.J.M., Wijnands, ir J.H.M., Huirne, prof.dr.ir.R.B.M., Kooten, van prof.dr.O.,Dordrecht: Springer/ Kluwer, (Wageningen UR Frontis series 15) p. 47-64. https://doi.org/10.1007/1-4020-469365 .

Ayag Z, Ozdemir RG. 2006. A Fuzzy AHP Aproach to Evaluating maChine tool alternative. Journal of Intelligent Manufacturing 17: 179-190. https:// doi.org/10.1007/s10845-005-6635-1.

Bolstorff P, Rosenbeum R. 2003. Supply Chain

Excellence: A Handbook for Dramatic Improvement Using The SCOR Model. New York: AMACOM.

Chopra S, Meindl P. 2007. Supply chain Management:

Strategy, Planning, and Operations, 2nd edition.
New Jersey:Prentice-Hall.

Fredenhall LD, Hill E. 2001. Basics of Supply Chain Mangement. Washington DC: The St. Lucie Press/APICS Series on Resource Management.

GunasekaranA.PatelC. Tirtiroglu E. 2001.Performance measures and metrics in supply chain environment. International Journalof Production and Operation Management 21(1/2):71-87. https://doi.org/10.1108/01443570110358468.

Heizer, Render. 2008. Principle of Operations Management, Operations Management. New Jersey:Prentice Hall.

Hugos M.2003.EssentialsofSupplyChainManagement. New Jersey: John Wiley \& Sons,Inc.

Hanugrani N. 2008. Pengukuran performansi supply chain dengan menggunakan supply chain operation reference (SCOR) berbasis analytical hierarchy process (AHP) dan objective matrix (OMAX). [tesis]. Malang: Program Studi Teknik Industri Universitas Brawijaya Malang. Malang.

Marimin, Maghfiroh N. 2010. Aplikasi Teknik Pengambilan Keputusan dalam Supply Chain Management. Bogor:IPB Press.

Mardhiyyah N. 2008. Kinerja penyampaian suku cadang PT Toyota-Astra Motor dengan model supply chain operations reference [skripsi]. Bogor: Departemen Manajemen, Fakultas Ekonomi dan Manajemen Institut Pertanian Bogor.

Mentzer, John T, De Witt W, Keebler JS, Min S, Nix, Nancy W, Smith CD, Zacharia ZG. 2001. Defining supply chain management. Journal of Business Logistics 22(2): 1-25. https://doi. org/10.1002/j.2158-1592.2001.tb00001.x.

Mutakin A, Hubeis M. 2011. Pengukuran Kinerja Manajemen Rantai Pasokan dengan Pendekatan SCOR Model 9.0 (Studi Kasus di PT Indocement Tunggal Prakarsa Tbk). Jurnal Manajemen 2(3):90-103.

Sumiati. 2006. Pengukuran performansi supply chain perusahaan dengan pendekatan supply chain operation reference (SCOR) di PT. Madura Guano Industri (Kamal-Madura) [tesis]. Surabaya: Fakultas Teknologi Industri UPN-Veteran.

Setiawan A. 2009. Studi peningkatan kinerja supply chain management sayuran dataran tinggi terpilih di Jawa Barat [tesis]. Bogor: Program Pascasarjana Ilmu Manajemen, Departemen Manajemen Institut Pertanian Bogor.

Setiawan A, Marimin, Arkeman Y, Udin F. 2011. Studi peningkatan kinerja supply chain management 
sayuran dataran tinggi di Jawa Barat. Jurnal Agritech 31(1): 60-70. https://doi.org/10.22146/ agritech.9727.

Satyanegara D. 2012. Analisis manajemen rantai pasok pada industri batik banten [tesis]. Bogor: Program Pascasarjana Ilmu Manajemen, Departemen Manajemen Institut Pertanian Bogor.
Supply Chain Council. 2006. SCOR. http://www. supply-chain.org/index.ww].

Van der Vorst JGAJ. 2005. Effective food supply chains: generating, modelling and evaluating supply chain scenarios [dissertation]. Wageningen: Wageningen University. 